\title{
First biosimilar of infliximab approved in Brazil: response from the Brazilian IBD society
}

\section{Professor Fabio V Teixeira, MSc, MD, PhD}

CT-P13 was the first infliximab biosimilar approved in Brazil. Approval was granted for all indications of the innovator. Despite similar efficacy and safety, vigilance remains essential.

Keywords: Biosimilar, CT-P13, infliximab, inflammatory bowel disease

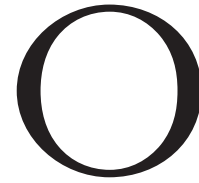

n 27 April 2015, the Brazilian Health Surveillance Agency (Agência Nacional de Vigilância Sanitária, ANVISA) approved the first biosimilar monoclonal antibody in Brazil. Remsima (CT-P13) is produced by the South Korean biopharmaceutical company Celltrion and will be marketed and distributed in Brazil by Hospira US [1].

This infliximab biosimilar is based on the originator drug Remicade, produced in the US by Janssen Biotech, Inc and distributed in Brazil by the same company [2].

Approval of Remsima was granted for all indications of infliximab based on its full clinical development, including two clinical trials: the phase I clinical trial PLANETAS, and the phase III clinical trial PLANETRA, which compared Remsima to Remicade in patients with active ankylosing spondylitis and rheumatoid arthritis, respectively. Several real life small series have subsequently been reported. So far, Remsima has shown similar efficacy and safety to the infliximab innovator in inflammatory bowel disease (IBD) patients. However, a randomized equivalence trial comparing Remsima with Remicade is still missing.

The approval of Remsima will reduce costs; most of the individuals currently using infliximab can only do so thanks to funding from the Brazilian Government. Approval of the biosimilar is commendable and approved by the medical societies involved. However, scientific, safety and pharmacovigilance issues have arisen and should be carefully addressed and widely discussed for the benefit of patients. Remsima has been approved for use in Brazil based on comparability strictly following the regulations of ANVISA [1]. Remicade, the infliximab originator, was approved in Brazil in 2001 for the treatment of Crohn's disease. This drug is also approved in our country for other uses: rheumatoid arthritis, psoriasis, ankylosing spondylitis, psoriatic arthritis, fistulizing Crohn's disease and adult/ paediatric ulcerative colitis. In line with the European Medicines Agency (EMA), ANVISA also follows strict international standards for approval of biosimilar drugs [3, 4]. As mentioned, Remsima has been approved by ANVISA based on comparability. To be approved by the Brazilian medicines regulatory agency, the drug has been successfully tested in humans in two clinical studies in rheumatology patients: a phase I clinical study in ankylosing spondylitis and a phase III study in patients with rheumatoid arthritis [5, 6]. The use of Remsima for other diseases listed in the reference drug Remicade package insert was approved based on the concept of extrapolation of indications [1].

In October 2014, the Commission of Biosimilar Drugs of the Brazilian Study Group of Inflammatory Bowel Diseases (GEDIIB) submitted to ANVISA an opinion contrary to the approval of Remsima for individuals with IBD [7-8]. Recently, the Brazilian Societies of Rheumatology, Dermatology and Gastroenterology (represented by GEDIIB) issued the same position [9]. Echoing the opinion of Health Canada, the Canadian agency responsible for the control of drugs, the opinion issued by GEDIIB made it clear that although the biosimilar drug is a positive and welcome measure in the IBD setting, it would be essential to carry out clinical studies with biosimilar products in a population with IBD so that these studies could settle any doubts regarding the efficacy and safety of the long-term use of this biosimilar drug $[7,10]$. It is well known in the academic community that only a small number of cases of IBD patients treated with Remsima have been published to date [11]. Moreover, it is known that there is still no prospective randomized study comparing Remsima with the reference drug Remicade.

On the other hand, after the product has been used for over a year in Eastern Europe and Korea, post-marketing studies presented at scientific events have reported good results regarding the efficacy and safety of Remsima used both in adult and paediatric patients with IBD [12-18]. However, a retrospective study conducted in Ireland using a controversial methodology showed a significant increase in hospitalizations, in the use of corticosteroids and in surgery among patients treated with Remsima compared with those who received the reference drug Remicade [19]. As this is to date the only study showing discrepancies in efficacy and safety between the biosimilar and the reference drug, it is vital that we carefully analyse these results and that we remain alert and vigilant. Our patients will certainly be grateful!

\section{Acknowledgement}

The author wishes to thank the English editing support provided by Dr Bea Perks, GaBI Journal Editor, for this manuscript.

Competing interests: The author is a consultant and member of the advisory board of Janssen, Hospira/Pfizer and Ferring.

Provenance and peer review: Not commissioned; internally peer reviewed.

\footnotetext{
References

1. ANVISA. Primeiro medicamento biológico por comparabilidade é registrado pela Anvisa. 27 April 2015 [homepage on the Internet]. [cited 2016 Jan 27]. Available from: http://s.anvisa.gov.br/wps/s/r/dhM6 2. Jung SK, Lee KH, Jeon JW, Lee JW, Kwon BO, Kim YJ, et al. Physicochemical characterization of Remsima. MAbs. 2014;6(5):1163-77.

3. Beck A, Reichert JM. Approval of the first biosimilar antibodies in Europe: a major landmark for the biopharmaceutical industry. MAbs. 2013;5(5):621-3.
} 
4. Reichert JM. Next generation and biosimilar monoclonal antibodies: essential considerations towards regulatory acceptance in Europe. February 3-4, 2011, Freiburg, Germany. MAbs. 2011;3(3):223-40.

5. Park W, Hrycaj P, Jeka S, et al. A randomised, double-blind, multicentre, parallel-group, prospective study comparing the pharmacokinetics, safety, and efficacy of CT-P13 and innovator infliximab in patients with ankylosing spondylitis: the PLANETAS study. Ann Rheum Dis. 2013;72(10):1605-12.

6. Yoo DH, Hrycaj P, Miranda $\mathrm{P}$, et al. A randomised, double-blind, parallel-group study to demonstrate equivalence in efficacy and safety of CT-P13 compared with innovator infliximab when coadministered with methotrexate in patients with active rheumatoid arthritis: the PLANETRA study. Ann Rheum Dis. 2013;72(10):1613-20

7. GEDIIB. Relatório do Grupo de Estudos da Doença Inflamatória Intestinal para ANVISA com respeito ao uso de biossimilar na DII. 2015 [homepage on the Internet]. [cited 2016 Jan 27]. Available from: http://gediib.org.br/?noticias\&dado_id=252

8. Teixeira FV, Kotze PG, Damião AO, Miszputen SJ. Biosimilars in inflammatory bowel diseases: an important moment for Brazilian gastroenterologists. Arq Gastroenterol. 2015;52(1):76-80.

9. Azevedo VF, de Souza Meirelles E, Kochen JA, Medeiros AC, Miszputen SJ, Teixeira FV, et al. Recommendations on the use of biosimilars by the Brazilian Society of Rheumatology, Brazilian Society of Dermatology, Brazilian Federation of Gastroenterology and Brazilian Study Group on Inflammatory Bowel Disease-Focus on clinical evaluation of monoclonal antibodies and fusion proteins used in the treatment of autoimmune diseases. Autoimmun Rev. 2015 Sep;14(9):769-73.

10. Health Canada. Health Products and Food Branch, Health Canada. Guidance for sponsors: information and submission requirements for subsequent entry biologics (SEBs) 2010 [homepage on the Internet] [cited 2016 Jan 27]. Available from: http://www.hc-sc. gc.ca/dhp-mps/alt_formats/pdf/brgtherap/applicdemande/guides/seb-pbu/seb-pbu-2010-eng.pdf

11. Kang YS, Moon HH, Lee SE, Lim YJ, Kang HW. clinical experience of the use of CT-P13, a biosimilar to Infliximab in patients with inflammatory bowel disease: a case series. Dig Dis Sci. 2015;60:951-6.

12. Kang HW, Lim YJ, Kim JH, Kang Y. An experience of anti-TNF biosimilar, CT-P13 use: clinical efficacy, safety and interchangeability in inflammatory bowel disease; a pilot study. J Crohn's Colitis. 2014;8(Suppl 1):S303.

13. Yoon Suk J, Park DI, Kim YH, Seo PJ, Kim JW, Kang HW. Efficacy and safety of infliximab's biosimilar (REMSIMA $\left.{ }^{\circledast}\right)$ for IBD. J Crohn's Colitis. 2015;9(Suppl1):S349-50.

14. Gecse K, Farkas K, Lovasz B, Banai J, Bene L, Gasztonyi B, et al. Biosimilar infliximab in inflammatory bowel diseases: first interim Results from a prospective nationwide observational cohort. J Crohn's Colitis. 2015;9(Suppl 1):S234-5.

15. Jarzebicka D, Banaszkiewicz A, Plocek A, Sieczkowska J, Gawronska A, ToporowskaKowalska, et al. Preliminary assessment of efficacy and safety of switching between originator and biosimilar infliximab in paediatric Crohn disease patients. J Crohn's Colitis. 2015;9(Suppl 1):S224-5.

16. Sieczkowska J, Banaszkiewicz A, Plocek A, Jarzebicka D, Gawronska A, Toporowska-Kowalska E, et al. Assessment of safety and efficacy of biosimilar infliximab in children with Crohn disease: a preliminary report. J Crohn's Colitis. 2015; 9(Suppl 1):S295.

17. Jarzebicka D, Plocek A, Sieczkowska J, ToporowskaKowalska E, Kierkus J. First observations of the use of biosimilar infliximab for treatment of ulcerative colitis in paediatric population. J Crohn's Colitis. 2015;9(Suppl 1):S307-8.

18. Molnar T, Farkas K, Rutka M, Bálint A, Nagy F, Bor R, et al. Efficacy of the new infliximab biomarker CTP13 induction therapy on mucosal healing in ulcerative colitis patients. J Crohn's Colitis. 2015;9(Suppl 1):S382.

19. Murphy C, Sugrue K, Mohamad G, McCarthy J, Buckley M. Biosimilar but not the same. J Crohn's Colitis. 2015;9(Suppl 1):S331-2

DOI: 10.5639/gabij.2016.0501.002

Copyright @ 2016 Pro Pharma Communications International 